\title{
Village Development Planning Discussion in Indonesia: Is It Working?
}

\author{
Syarifuddin $^{1}$ and Ratna Ayu Damayanti
}

\author{
${ }^{1}$ Hasanuddin University \\ ${ }^{2}$ Hasanuddin University
}

\begin{abstract}
The purpose of this study is to describe the problems in village musrembang which is a planning model implemented by the Indonesian government at the village level. This research is essential to determine whether musrembang is useful to encourage community participation in the planning process of developing their villages. This study uses phenomenology as a method to capture planning problems in the village government (musrembang). This method will be operated to reveal, who dominates the discourse in organized musrembang? The findings of this study indicate that people have limited involvement in musrembang. Musrembang is only a formal process that is pseudo participatory, musrembang that the government carries out does not work effectively to encourage public participation in planning village development.

Keywords: village, Indonesia, musrembang, planning, participatory, community.
\end{abstract}

\section{Introduction}

The need to include local participation in development and planning projects has attracted more considerable attention in recent years (Scoones and Thompson, 1994; Carney, 1998; Scoones, 1998; Bebbington, 2000). This attention is especially in relation to sustainable development (Adams, 1990; Merchant, 1992; Escobar, 1996), and in terms of participatory rural appraisal (Chambers, 1994a, 1994b, 1997; Moser, 1998), as well as in the local political community (Hecht, 1985; Blaikie and Brookfield, 1987; Peet and Watts, 1996; Bryant and Bailey, 1997; Blaikie, 1999). Although this tradition has a different purpose, they have the same common interests in dealing with local-scale processes using participatory methods. In recent years, advocates of this method have begun to integrate Participatory Rural Appraisal (PRA) with multimedia tools. This is done to represent an alternative knowledge in the planning process in order to present local experience and control of geographic space in developing countries for national and international bodies (Brown et al., 1995; Harris et al., 1995; Peluso, 1995; Rocheleau and Ross, 1995; Hodgson and Schroeder, 1999).

This is important to realize good governance that benefits community equally. To understand the community welfare, the government must carry out equitable development that accommodates community participation in planning following the principle of Pancasila, namely the fourth principle. Meaning, in addition to maintaining its legitimacy, the government, through cooperation, can also create progress for the community following each era.

Moreover, to be able to plan under the principles of Pancasila, two things must be implemented by the government. First, it should be aspirational to the aspirations articulated by the community, as well as being sensitive to the community needs. The government needs to know what is required by the people and to listen to what they want. Second, the government needs to involve all the will and abilities possessed by the community in carrying out development. In other words, the government needs to place people as the subject of construction, not just as objects of development.

Related the statements above, the lack of community role in participation, especially regarding poverty and village planning, led to the widening gap between public and government. In term of debt, the poverty gap that occurs in rural areas is also widening. This is due to poverty reduction merely being a central government project through the musrembang program, or just ad hoc nonsustainable following the character and social capital owned by the villages. Because it's merely a project, the sustainability of the program cannot be guaranteed, which then results in the lack of community participation. Consequently, the villagers did not feel like they own then the results of 
these programs from development, especially the physical applications. If this is reviewed further, we will see it is not in line with the fourth principle of Pancasila, namely democracy, deliberation, and consensus. It can be said that musrembang in various aspects are just pseudo participatory which did not include the entire community in planning.

According to the above discussion, this study aims to explore, the effectiveness of musrembang as a means to improved community participation in addition to assessing the inclusiveness of community in village development planning.

The participatory development paradigm has been practiced by many countries so far. But, in some cases, the practice is not following the nature of the actual participatory approach. Some of the methods characteristics that are not in accordance with the spirit of participation are: 1) sector oriented, region basis are less considered; 2) short term and quantitative, capability increase effect of the community through the long-term learning process is not a consideration; 3 ) focused on providing resources/services, organizational development, and norms of society is less considered; 4) tools and techniques oriented, participation is intended more as an instrument to gain information and aspiration for project planning; 5) in practice has a non-functional perspective, where the project is carried out without considering the functional capacity of the community (Oviasuyi et al., 2010).

The above phenomenon shows that the current development is highly prioritizing the success of material/physical elements without considering non-physical aspects such as the spirit, values, culture, and aspirations of the community. Therefore, development practices have experienced improved performance when viewed in terms of the success in their quantitative program/project, have involved the community nominally in development, and have enriched the tools/techniques in the situation analysis and problem identification/needs through application Rapid Rural Appraisal (RRAS), Participatory Rural Appraisal (PRA), Participatory Local Social Development (PLSD) and other similar techniques. This complete technique source originates from Participatory Action Research (PAR) or Participatory Local Action (PLA). Nevertheless, further benefits in the form of society capability increase for independent sustainable development has not been achieved. The development programs/projects that were completed gave minimal "learning impact through experience" to the community. This happens because the concept of participatory described above is not applied correctly.

In many cases, the participatory approach even manages to become a new co-optation of the ruling regime which is not a means of liberation. Thus, the face of oppression from actual development remains, only wrapped up in the participation jargon. After three decades of progress in developing countries (Indonesia), the country became the sole authority while the people were only participants. Over time, new ideas developed that the development was supposed to be by the people themselves and outsiders were only facilitators in empowering the people. Under the latest thinking, the pressing agenda is how to usher people to arrive at the position to be agents of development, both in terms of ability and institutional aspects. It is advised that growth becomes more meaningful with "capability building and institutional strengthening" in low-income, marginalized, and helpless communities as the target of development.

The concept of participation then shifts its meaning, from being active (people's involvement in development) to a verb (an approach to bring people into event). The participatory approach becomes a popular jargon behind this shift in meaning. Philosophically, developing a participatory approach is based on the principle "experience-based learning process" for capability building and institutional strengthening where this concept becomes a significant thing in the implementation of development In the case of development of a project in the countryside, in the absence of criteria and indicators that have been agreed with the communities, the different assumptions related to rural development can be made by various people about what should be considered as a sign of 'good rapport' (Martin, 1995). This term describes the relationship between external parties (in this case the government) and the community and implies trust, agreement, and cooperation required to achieve a participatory approach to development. However, this relationship is usually depicted only from one point of view, 
namely from the outside. Effective 'rapport' in practice generally represents a set of outside assumptions of village 'accessibility' and allows effective communication with the public (Garcia and Lescuyer, 2008). How easy is it to introduce the Participatory Rural Appraisal (PRA) method at the beginning, and whether it helps in the development of rapport (meaning, the process record through which they reach consensus) with the local community, this is a big challenge. 'Rapport' itself is an information record that is very difficult to identify (Garcia and Lescuyer, 2008). In building rapport, several field researchers stress the importance of participation in village meetings where the purpose of the construction project was explained to the public, while other researchers would emphasize the strength of the relationship with local leaders, and others pointing the importance of the number of household visits (e.g., Schonhuth and Kievelitz, 1994; Martin, 1995; Almedom et al., 1997).

Some issue in the new use of PRA in village planning is the false and wrong assumptions when reading the 'rapport' signs. In practice, communication with the community and gaining acceptance for the development project activities to be implemented is a complex process. The initial movement is the basis for participatory society (Omar, 2012).

Some initial experience in the village over the plan a development project indicates that villagers respond to government staff not as a well-received funder but, based on some studies, the villagers have concerns with outsiders. In rural areas, contacts with outsiders who are new to the community are generally regarded as a threat and a risk and not as opportunities and new resources and positive (Schonhuth and Kievelitz, 1994; Martin, 1995; Almedom et al., 1997). The most common village community concerns are related to land rights. For example, they are reducing the project development rights to land by constructing dams and drown valley land, government land reclamation for plantations, or by acquiring land for industrial development. These examples are all part of the experience of the village "development projects". Therefore, in this context, the terms used to express project objectives must be carefully determined (Almedom et al., 1997).

Experience passed down from generation to generation indicates that outside parties pay attention to rural issues only if they have an interest in villages that are their goal. Furthermore, these interests are usually being express as to meet the village's needs to do 'development'. The most important question in the minds of the villagers, and project staff should give a satisfactory answer to, is 'who are you, and what are your interests toward us?' Communicating acceptable answer to the question through an appropriate idiom is a prerequisite to rapport construction or information gathering activities such as PRA (Schonhuth and Kievelitz, 1994; Martin, 1995; Almedom et al., 1997).

However, the next question arises whether PRA activities can create a situation that does not threaten and capable of explaining the purpose of the development project and opening a dialogue. Of course, the effectiveness of PRA as a research method is often considered to depend on the 'rapport' produced and is an informal participatory collaboration with the village community (for example, living with villagers, sitting at the same level, and other familiarity methods that needs to be established with village community) (Garcia and Lescuyer, 2008).

Rapport level of an outside party with the community at the beginning of planning generally comes from the interaction of outsiders with a limited number of individuals, who function as intermediaries or mediators between outsiders and the community. One wrong perception of the rural development from 'community leaders' (as the mediator) is a source of communication failures which have implications on the initiative of development projects in the future. In one or two situations, inability to understand local styles and leadership patterns adequately can seriously affect efforts to do PRA seriously.

To implement an organized PRA, it is necessary to involve a group of outsiders to live in a village and demonstrate their commitment to the village community project development. If this is not based on building compromise between the two parties (village and project planner), PRA may end up giving an artificial choice to the town, 'whether they want the initiative or not,' before they realize the implications of choice given. Therefore, it needs to be organized planning such as the appraisal rural participatory (PRA) model to avoid the risk of rejection from the local community. In such 
situations, organized PRA must be carried out through friendly cooperation over a longer period with individuals or groups in the community. In other cases, concrete actions involving commitment between the project planners and villages are needed before a more formal PRA can begin. For example, by carrying out activities such as inviting village communities to visit participatory development initiatives in other places or organizing community groups' visits to another village nearby who has more experience with the construction of a similar project. On the other hand, as indicated by the creation of a project in the countryside, organized PRA is an effective way to win support for project activities.

Finally, several studies of the use of PRAs in rural project development have shown that effective communication with villagers is not only determined by factors in rural communities (such as local concerns about land or leadership patterns), but also by the administrative and political context broader than tribal development in the region (Garcia and Lescuyer, 2008). The critical thing to note is bureaucracy, and political system in a village is very sensitive related to researchers working in the tribal areas. Therefore, researchers need to develop sincerity and credibility with local institutions to become an essential part in developing the participatory strategy.

A brief sketch of a PRA study will be described to determine the background of the next discussion. In short, the entirety objectives of a development project are 'to improve wildlife to poor farmers in the long term by encouraging a participatory system and focuses on poverty through the improvement of participatory development system approach (Kolb, 1984). PRA research intends to enhance local capacity in the management of natural resources and to improve the ability of poor rural communities in gaining access to government programs that exist. This is important to create sustainable development and improve the socio-economic conditions of poor farming families. This research strategy involves a long process of participatory planning where PRA engaged in producing natural resources development plan specific to each village. This consists in prioritizing issues that must be resolved and identifying opportunities for innovation, including better use of alternative development.

\section{Research Methodology}

In this study, phenomenology is used to raise a view of local information and knowledge that is different from what is commonly used in the practice of musrembang. Information is not only 'out there' waiting to be 'collected' or 'found,' but is built or made, in a particular social context for a particular purpose. Specifically, this research raises the implications of (a) social domination and authority; (b) gender relations; and (c) the existence of 'outside parties' projects, in the formation and recording of public information available to make plans. In the case of gender, for example, the question that can be asked is how women's ability to participate fully in musrembang? How far the knowledge, competence, and experience of women can be 'accessed' using musrembang method? Phenomenology refers to a thinking method of acquiring new knowledge or develops existing knowledge with logical steps, critical systematic, not based on a priori/prejudice, and not dogmatic. Phenomenology as a method is not only used in philosophy but also social sciences and education. Phenomenological research involves a careful and thorough testing of the consciousness of human experience. The central concept in phenomenology is meaning. Meaning is a relevant content that arises from the experience of human knowledge. To identify essential qualities from experience, consciousness is carried out in-depth and meticulous way (Smith et al., 2009, 11). Husserl first introduced the principles of phenomenological research. Husserl introduced ways to expose meaning by explicitly structuring the experience that is still implicit. Different concepts of phenomenology are Intensity and Intersubjectivity, as well as recognizing the phenomenological term Hermeneutic that was introduced by Heidegger. Every day humans are busy with activities, and activities that are full of experience. The essence of knowledge is then built by two assumptions (Smith et al., 2009, 12). First, every human experience is an expression of consciousness. Someone experiences something. $\mathrm{He}$ is aware of his own subjective experience. Second, every form of awareness is always an awareness of something. When we see the car passing us, we think who is driving it, expecting to 
have a car like that, then wanting to go with that car. Just as robust as wanting to travel in a car like that, at the same time, it can't happen. These are all activities that occur in everyday life, a natural attitude. Self-awareness reflects on something that is seen, though, remembered and expected; this is what is called phenomenology. Phenomenological research focuses on something experienced in individual consciousness, which is called intentionality. Intentionality describes the relationship between processes that occur in awareness with the object of concern in the process.

Regarding phenomenology, experience or consciousness is always an awareness of something, seeing is looking at something, remembering is remembering something, judging is evaluating something. Something in these statements is objects of consciousness that have been stimulated by the perception of an object that is "real" or through the act of remembering or creativity (Smith et al., 2009, 12). Intensity is not only related to the purpose of human action but is also the central character of the mind itself. The intention is never the mind itself but is always thought of something. The account still has an object. The same thing applies to consciousness. Intentionality is a directedness of knowledge. And intentionality is also the directivity of actions, namely actions that aim at one object. Husserl's phenomenology method (2009) starts from a series of reductions. A reduction is needed for intuition to capture the nature of objects. These reductions remove all the aggravating things when we try to achieve wesenschau. The first reduction gets rid of everything subjective. Our attitude must be objective, open to symptoms that must be "talked about." Second, removing all knowledge about objects that are investigated and obtained from other sources. Third, remove all the reduction of experience. Everything that others have said must be temporarily forgotten. If these reductions are successful, the symptoms can show themselves, become phenomena (show themselves). According to Smith et al. $(2009,14)$, each cut provides a difference in lens or prism, and different ways of thinking and decision making based on logical thinking about phenomena from a different perspective. The structure of reduction is planned to guide the researcher away from the confusion and misdirection of assumptions and preconceptions and return to the essence of experience from given phenomena. In phenomenology, testing is done with descriptions and reflections on every important thing, especially from the given event.

The description of a phenomenological experience is only the first stage. The real thing done in testing is to get more general experience. Testing is done by trying and determining whether the essence of experience is subjective and whether the essence or idea of the object (Smith et al., 2009, 14). Phenomenology also holds reflections on direct experience or reflection on symptoms/phenomena. By reflecting, researchers will get a true and profound understanding. In phenomenology, it is advised to see what is experienced by humans from the perspective of the first person, that is, from the person who experienced it. The focus of phenomenology is not a particular experience but the experiencing structure of consciousness, namely the objective reality that manifests in the subjective experience of someone. Phenomenology focuses on the personal meaning of objective truth in the knowledge of people who live their daily activities.

\section{Result and Discussion}

Successful implementation of community development highly depends on the role of government and community. Both should try to create synergy. Without involving the community, the government will not be able to achieve development results optimally. The development will only give birth to new products that are less meaningful for the city, as well as not following the needs of the community. Likewise, without an optimal role from the government, the development will run irregularly and in a non-directed manner, which will eventually lead to new problems. Besides requiring community involvement, the event also requires the right strategy to be more efficient in terms of financing and effective in terms of results. The selection of this development strategy is essential because it will determine where the role of the government is and where the part of the community is, enabling both parties to play an optimal and synergistic role. 
In addition to the mandate carried out in Law No. 23 of 2014, development planning and implementation must be downward oriented and involve the wider community, through the granting of development planning and implementation authority at the regional level. This way, the government will be increasingly able to absorb the aspirations of many people, hence allowing the development to empower and fulfill the needs of the people at large. The people must be actors in progress, the community needs to be fostered and prepared to be able to formulate their problems, plan the necessary steps, implement the programmed plans, enjoy the products produced and preserve the programs that have been formulated and implemented, primarily related to planning at the village level.

Dehaene (2012) explained that community development is seen from the change mechanism to achieve its objectives, there are community development activities that prioritize and emphasize on how the process is until a development result can be realized, however, there are those who put more emphasis on real results. In the sense that, understanding the process and mechanism of change to achieve a tangible outcome is not much of a concern, and the important thing is how they can see a result physically in a relatively short time. The first approach is often referred to as an approach that prioritizes the process and emphasizes more on the human aspect, while the second approach is called an approach that prioritizes real results and highlights the target.

In general, community development is an activity carried out systematically, planned and intended to expand community access to achieve social, economic, and quality of life that is better when compared with the condition before construction activities. With this basis that, in general, the scope of programs of community development can be divided into the following categories: (1) community service, (2) community empowerment, and (3) community relations (Scoones, 1998).

Garcia and Lescuyer (2008) explain that the National Development Planning System (SPPN) has been further elaborated into Government Regulation (PP) No. 39 and No. 40 of 2006. This planning system is expected to coordinate all development efforts carried out by various development actors hence able to produce optimal synergies in realizing the goals and ideals of the Indonesian people. Based on this, the social change process (or "development") needs to be carried out in a planned, coordinated, consistent and sustainable manner, through "the role of government and society" by taking into account economic conditions, socio-political changes, existing socio-cultural developments, scientific developments and technology, and international development or globalization (Okpani and Abimbola, 2015).

Neumann (1995) also stated that in mobilizing improvements in conditions and enhancing people's living standards, participation planning must be carried out with effort: (1) plan must be adapted to the needs of real people (felt need); (2) is used as community stimulation, which functions to encourage the emergence of responses; and (3) be a motivation to the community, which serves evoke behavior. In participatory planning, people are considered as partners in planning who actively participate, both in terms of the preparation and implementation of the plan because the community is the most significant stakeholder in the development of a product plan.

Likewise, Ohama (2001) added that as a further reflection of democratization and participation which is part of good governance, development planning process also goes through a participatory process. Participatory planning thinking begins with an awareness that the performance of a community development initiative is determined by all parties related to the effort. Since the introduction of the participatory planning model, the term "stakeholders" has become very widespread and finally considered as an idiom of this model. Sopanah and Wahyudi (2005) affirms that rural development efforts through a participatory planning process needs to be approached with a variety of ways, such as: (1) extracting a variety of potential that can be built by the local community; (2) development of appropriate technology which includes the creation, development, dissemination and use of technology by rural communities; (3) fostering business organizations or implementing units that implement various appropriate technologies to achieve development goals; (4) promoting building/support organization, which links the development efforts carried out by individual residents 
of rural communities with other institutions or with higher level (cities, districts, counties, region, and national); and (5) development of supporting policies, which include inputs, credit costs, marketing, and others who provide harmonious climate for growth.

Meanwhile, Chambers (1983) states that the development planning process based on community participation must pay attention to the interests of the people that aim to improve the welfare of the community. Therefore, in the planning process, there are some things that need to be considered including: (1) planning program should be based on facts and reality in community; (2) program should take into account the ability of the citizens in terms of engineering, economics, and social; (3) application should consider elements from interest groups in society; (4) community participation in the program implementation; (5) Extensive involvement of existing organizations; (6) program should include short-term and long-term plan; (7) Offers ease of evaluation; and (8) program should take into account the conditions, money, time, tools, and available energy.

Therefore, with Law No. 25 of 2004, Indonesia has demonstrated that development planning is a bottom-up, which emphasizes the participation of many parties in the implementation of the development. The involvement of many parties in regional development planning can be realized through a Development Planning Consultation (musrembang). Musrembang becomes a container for development planning document preparation and coordination among government agencies and the participation of all development actors. Besides, Act No. 25 of 2004 contained in Article 1 paragraph 3 explains that SPPN is an integral part of development planning procedures to produce development plans in the long term, intermediate term, and yearly, carried out by elements of the implementation of state and society both at the central and local.

Moreover, article 2 paragraph 4 states that the SPPN goal is: 1) support condition among development actors; 2) guarantee integration, synchronization, and synergy creation between regions, space, time, functions of government, as well as between the central and local; 3) assure linkages and consistency between planning, budgeting, implementation, and monitoring; 4) optimizing community participation; and 5) ensure the achievement of resource use in an efficient, effective, equitable, and sustainable way. The law also describes the 4 (four) stages of the planning process, namely: the first stage, development plan draft preparation that is technical, comprehensive, and measurable. In this situation, foreign government agencies prepare work plan draft based on the development plan draft that has been made. The second stage involves the community (stakeholders) and aligning development plans produced by each level of government through consultation on development planning, which starts with the implementation musrembang in village level, musrembang in subdistrict level, musrembang in district level. The third phase is the final draft preparation of development plan. This step is carried out based on the results of musrembang districts. The last step is establishing planning into the right product that binds all party to carry it out.

After the development plan is established, according to the law, control is carried out on its implementation. Implementation control of development planning was meant to ensure the achievement of goals and objectives contained in the plan. Inspection is done by observing the implementation of the activities in the preparation and to do corrective action and adjustments during the implementation of the project by the head of the institution/ unit work area. Furthermore, the head of the Regional Planning Agency (Bappeda) will gather and analyze the implementation monitoring results of development plans from each institution leaders/working units according to their tasks and authority.

After the information on activities implementation was collected, the head of Bappeda conducts an evaluation. Evaluation of activities implementation is part of a systematic development planning activities by collecting and analyzing data and information to assess the achievement of goals, objectives, and performance development. This evaluation is carried out based on the indicators and performance targets listed in the development plan document. How to evaluate the implementation of the activities set forth in article 3 of Government Regulation No. 8 of 2008 on Stages, Preparation Procedures, Controlling, and Evaluation of Local Development Plan which states that planning for 
regional development are formulated in a transparent, responsive, efficient, effective, accountable, participatory, scalable, equitable, and sustainable way. In some of these regulations, it has been mentioned about the need for community participation in the implementation of development planning. Thus, governments in Indonesia chronologically ranging from the upper level to the lower levels already have procedures, documents, and rules that are quite good and have considered inclusiveness in the regulations. It's just that the rules are not implemented at a practical level, as observed in this study.

According to results on the preliminary observations, there are some irregularities in musrembang conduct on several villages in the districts of the research object, which is during the musrembang process being performed, a list of proposals that will be proposed to the area has been in print by the sub-district. Hence, it appears as if the process of musrembang implementation for Sub-district Barru District Barru (one of a case) does not indicate there is prioritization of activities carried out jointly/in groups in a forum. It appears that there a tendency for the proposal that is submitted to the district is a formulation based on a list of recommendations from subdistrict authorities of each urban/rural and services/agencies. Additionally, musrembang was only attended by the parties of the official/government agencies, none of the representatives of the other parties, it is following the description Rahmat, a village board, who stated that, Sub-district musrembang will be ideal if it is followed by every community component (individual/group). Components communities, consists of: region represented by rural/village delegation team, a Members of Parliament from the constituency (electoral district) whom is concerned, organization of society and non-governmental organizations that have a working area in regions involved, social groups and women's representation (community leaders, traditional leaders, religious leaders, fathers, mothers, and other marginalized groups), businesses representation in the concerned district area which is based on its ability to increase local resources.

Based on the data that has been mentioned above it can be concluded that the participation of development actors lacks in the implementation of sub-district musrembang, particularly of the community components and non-governmental organizations. This raises their tendency that the determination of development priorities that was conducted in Barru is merely a decision of the government apparatus without the involvement of the public and other non-governmental parties, which may result in implementation development that does not favor community. A similar view occurred in other regions that became the object of research such as villages in Gowa and villages in Luwu.

According to researches and studies literature results in some cities/regencies in Indonesia, it can be concluded that the level of community participation in musrembang was limited to the level of 'consultation.' While there are musrembang forums, the final decision remains in the hands of the government, as expressed by Syarifuddin (2011) and Damayanti (2011) that the elite of power dominates the decision for development process. Such conditions according to Arnstein's $(1971,70)$ participation ladder are referred to as "tokenism" or false participation, where awareness of participating communities at various levels of government is "false consciousness" or "pretend awareness." 
Table 1. Stages and Problems

\begin{tabular}{|c|c|}
\hline Stages & Problems \\
\hline Planning & $\begin{array}{l}\text { - Community suggested in musrembang turns out to be plenty. Starting from the result } \\
\text { document, we see a lot of suggestions. A village chief even claimed to have a } \\
\text { headache from seeing proposals from many people, while village government felt } \\
\text { confused as to how to realize these proposals. } \\
\text { - Furthermore, musrembang proposals was still dominated by the physical } \\
\text { development agenda, for instance, construction of roads, bridges, village offices, } \\
\text { uniforms, and so on. While the agenda of its ongoing and much needed health and } \\
\text { education services are rarely proposed by the community. } \\
\text { - Other substantial problem is inconsistency between the results of planning and } \\
\text { budgeting, especially when it went to sub-districts and districts. This is because the } \\
\text { budget for many of the results of the musrembang process are not availabl and as a } \\
\text { result, the plan cannot be realized. It was the one that makes many people feel } \\
\text { uninterested with musrembang activities. They consider musrembang as an act that } \\
\text { waste energy and time, because the budget ceiling related to expenditure items has } \\
\text { been determined from the higher-up. }\end{array}$ \\
\hline & $\begin{array}{l}\text { - Musrembang member still dominated by the apparatus and the elite in power, while } \\
\text { the community participation, especially women's groups are very minimal. In fact, } \\
\text { development projects such as school construction or the construction of health posts } \\
\text { all require women's participation because they are connoisseurs and user of these } \\
\text { development results. } \\
\text { - Musrembang tend to be just a formality on the account of people become uninterested } \\
\text { because their proposals are not accommodated, they are less represented because the } \\
\text { representation is based on formal. For example, represented by the head of the } \\
\text { village. As a result, musrembang forum has not reached a participatory expected } \\
\text { because only } 10 \% \text { of the local community are active; } 50 \% \text { are sometimes or rarely } \\
\text { involved; and } 40 \% \text { is never involved. } \\
\text { - Factor that also greatly affects this is the capacity of both the residents and village } \\
\text { cadres and are so few that the level of absorption of information, creativity, and their } \\
\text { insight in understanding the planning was minimal. Therefore, the presence of those } \\
\text { with a minimum of around } 10 \% \text { becomes a consultative presence or just comes and } \\
\text { is present, without knowing the meaning of the planning process itself. }\end{array}$ \\
\hline
\end{tabular}

Source: processed data

Based on field results, researcher divide problems into two main issues in planning, namely: first, the issues associated with the substance of the plan, and second, the issues related to the planning process. Planning substance is described in the table above.

Nevertheless, something is encouraging in the result implementation process. The community is actively involved in the program implementation by the village government as both implementers and beneficiaries. They still have an excellent going royong spirit because they even participating in the development implementation. However, community involvement in the supervision of development is minimal. This is because decisions are generally taken by the higher up and reached the community only in the form of socialization that cannot be rejected.

Also, communication practices that are only through hierarchy can potentially be elite capture (only benefit a small group of people) and hinder a thorough understanding of new information. The presumption that the village elite will automatically deliver the information they receive to the rest of society does not always happen. Village elites have the power to sort out and choose what information will be provided and to whom it is delivered. As previous studies (Syarifuddin, 2011; and Damayanti, 2011) show, the budgeting process is where musrembang is one of the methods that show the 
dominance of government elites in the process, both executive and legislative, and there is a bargaining program/priority among them. The community does not have any position in the process. Whereas according to observations of field conditions, to obtain information formally, the village government can use the village hall as a social institution. Many people can attend most meetings in the village hall. Additionally, informal information exchange can also occur in the public sphere such as when riding in the fields or washing/bathing in the river. However, the village government needs to be careful because the exchange of information in the informal sphere is prone to distortion because many sources may misinterpret the meaning of the information obtained. Therefore, there needs to be more than one source and channel to get information so that all relevant parties can get a thorough understanding of the concepts and techniques of village government programs or activities, such as the distribution of brochures in the market or crowd center either in written form or in pictures for illiterate people. Therefore, the necessary condition in village planning can be seen in the following table:

Table 2. Required condition

\begin{tabular}{|c|c|}
\hline Issue & Required Condition \\
\hline $\begin{array}{l}\text { Planning and } \\
\text { budgeting } \\
\text { information }\end{array}$ & $\begin{array}{l}\text { There must be sufficient information regarding priorities and estimates of budget } \\
\text { allocations for development in the planning year. This information is a filter for } \\
\text { proposed activities that is suggested at the participatory planning level (Village, } \\
\text { Sub-district, District Musrembang) }\end{array}$ \\
\hline $\begin{array}{l}\text { Officials } \\
\text { commitment }\end{array}$ & $\begin{array}{l}\text { The planning process must have a direct impact on the sector, and thus authorities } \\
\text { are present in important planning and budgeting processes }\end{array}$ \\
\hline $\begin{array}{l}\text { Conversion } \\
\text { method }\end{array}$ & $\begin{array}{l}\text { There must be in-depth discussion and verification between the community (who } \\
\text { submitted the proposal) and those who have competence in the relevant field }\end{array}$ \\
\hline Format used & $\begin{array}{l}\text { - There must be a good format and information system regarding the conversion } \\
\text { process of proposals from the region to the sector to ensure the smooth process } \\
\text { of subsequent planning and improve participatory planning accountability. } \\
\text { - The process of documenting planning and budgeting if possible, to be done } \\
\text { digitally and to not cause different interpretations between actors. }\end{array}$ \\
\hline $\begin{array}{l}\text { Planning and } \\
\text { budgeting } \\
\text { process flow }\end{array}$ & $\begin{array}{l}\text { There must be a direct relationship between the participatory planning process and } \\
\text { the budgeting process. }\end{array}$ \\
\hline Time & The order of planning and budgeting documents preparation must be consistent \\
\hline $\begin{array}{l}\text { Community } \\
\text { representation } \\
\text { and control }\end{array}$ & $\begin{array}{l}\text { - Participants who follows in participatory planning were not only regional } \\
\text { representation but also representation of functional groups (farmer groups, } \\
\text { fishermen, and NGOs). } \\
\text { - The community must be involved in the budgeting process }\end{array}$ \\
\hline Capacity & $\begin{array}{l}\text { The facilitator must be able to distinguish the relevant programs to be submitted } \\
\text { to the district level }\end{array}$ \\
\hline
\end{tabular}

Source: data processed

Facts show that the chance of people obtaining information both technical and non-technical related to the implementation musrembang is often limited to the extension field visits. Although there is a visit, the information conveyed is often challenging to understand by ordinary people and without any follow-up.

\section{Conclusion}

This study shows that public participation in development is generally just normative, passive, and sometimes consultative. When communities, both directly and through representation, relate to 
government institutions at a higher level, participation tends to be inactive or consultative. In this case, musrembang is only a formal program.

The findings of this study indicate that the input or community involvement in musrembang is scarce, while the process is more top-down that it prevents people from conveying their ideas. Besides, the musrembang output appears merely as a list of wants rather than needs so that they are not appropriately filtered to be brought to a higher level of deliberation (musyawarah).

This study implies that openness to new things and the possibility of changes in the planning and implementation stages of the program need to be continually encouraged. This process includes gathering various criticisms from the previous steps, which have not been carried out because of the limitations of time and space and using them as input to plan for the future. 'Nominal participation' in groups provides an opportunity to encourage openness and information sharing between various parties on an ongoing basis (temporal transparency).

\section{References}

Adams, W.M. (1990). Green development: Environment and sustainability in the Third World. New York: Routledge.

Almedom, A.M., Blumenthal, U., \& Manderson, L. (1997). Hygiene evaluation procedures: approaches and methods for assessing water and sanitation-related hygiene practices. International Nutrition Foundation for Developing Countries. Boston, Massachusetts.

Arnstein, S.R. (1971). Eight Rungs on the Ladder of Citizen Participation. Dalam Cahn, E.S., \& Passet, B.A. Citizen Participation: Effecting Community Change. Praeger Publishers: New York.

Bebbington, A. (2000). Reencountering development: livelihood transitions and place transformations in the Andes. Annals of the Association of American Geographers, 90 (3). Pp. 495-520.

Blaikie, P. (1999). A review of political ecology: issues, epistemology, and analytical narratives. Zeitschrift fur Wirtschaftsgeographie, 43 (3-4). Pp. 131-147.

Blaikie, P., \& Brookfield, H. (1987). Land Degradation and Society. (eds). Methuen: London.

Brown, L.A., Alechandre, A.S., Sassagawa, H.S.Y., \& De Aquino, M.A. (1995). Empowering local communities in land-use management. Cultural Survival Quarterly, Winter. Pp. 54-57.

Bryant, R., \& Bailey, S. (1997). Third World Political Ecology. Routledge, London: UK.

Carney, D. (1998). Sustainable rural livelihoods: What contribution can we make? (eds). DFID, London: UK.

Chambers, R. (1983). Rural Development: Putting the Last First. Longman Scientific and Technical: London.

Chambers, R. (1994a). The origins and practice of participatory rural appraisal. World Development, 22 (7). Pp. 953-69.

Chambers, R. (1994b). Participatory rural appraisal (PRA): Analysis of experience. World Development, 22 (9). Pp. 1253-68.

Chambers, R. (1997). Whose Reality Counts? Putting the First Last. Intermediate Technology Publications: London, UK.

Damayanti, R.A. (2011). Hubungan Keagenan Pemerintahan Daerah Dalam Konteks Anggaran: Sebuah Agenda Rekonstruksi (Agency Relationship of Local Government in Budget Context: A Reconstruction Agenda). Journal Ekuitas, Vol. 15 No. 2. pp. 149-171.

Dehaene, M. (2012). More Than Projects. In Changing Cultures of Planning: Rotterdam, Zurich, Nantes, Randstad, Bordeaux, edited by N. Baes-Cantillon, J. Declerck, M. Dehaene, and S. Levy, 9-14. Brussels: Architecture Workroom Brussels.

Escobar, A. (1996). Constructing nature. Dalam Peet, R., Dan Watts, M. (eds). Liberation ecologies: Environment, development, social movements. Routledge: London, UK. Pp. 46-68. 
Garcia, C.A., \& Lescuyer, G. (2008). Monitoring, indicators and community-based forest management in the tropics: pretexts or red herrings. Biodiversity and Conservation, 17. Pp. $1303-1317$.

Harris, T.M., Weiner, D., Warner, T., \& Levin, R. (1995). Pursuing social goals through participatory GIS: Redressing South Africa's historical political ecology. Dalam Pickles, J. (ed.). Ground truth: The social implications of geographic information systems. Guilford: New York. pp. 196-222.

Hecht, S. (1985). Environment, development, and politics: Capital accumulation and the livestock sector in Eastern Amazonia. World Development, 13 (6). pp. 663-84.

Hodgson, D.L., \& Schroeder, R.A. (1999). Mapping the Maasai: Dilemmas of counter-mapping community resources in Tanzania. Paper presented at the African Environments: Past and Present conference at St. Antony's College at Oxford. The United Kingdom.

Kolb, D.A. (1984). Experiential Learning. Experience as the Source of Learning and Development. Prentice-Hall Inc. Englewood Cliffs: NJ, USA.

Martin, G. J. (1995). Ethnobotany: a methods manual. Chapman \& Hall: New York.

Merchant, C. (1992). Sustainable development. In Merchant, C. (ed.). Radical ecology: The search for a living world. Routledge: New York. pp. 211-234.

Moser, C.O.N. (1998). The asset vulnerability framework: Reassessing urban poverty reduction strategies. World Development, 26 (1). pp. 1-19.

Neumann, R.P. (1995). Local challenges to global agendas: Conservation, economic liberalization and the pastoralists' rights movement in Tanzania. Antipode, 27. pp. 363-82.

Okpani, A.I., \& Abimbola, S. (2015). Operationalizing universal health coverage in Nigeria through social health insurance. Nigerian Medical Journal, 56(5). pp. 305-310.

Omar, M. (2012). Ensuring free, fair and credible elections in local governments in Nigeria. Developing Country Studies, 2(11). pp. 75-81.

Oviasuyi, P.O., Idada, W., \& Isiraojie, L. (2010). Constraints of local government administration in Nigeria. Journal of Social Sciences, 24(2). pp. 81-86.

Peet, R., \& Watts, M. (1996). Liberation ecologies: Environment, development, social movements. (Eds). Routledge: New York.

Peluso, N. (1995). Whose woods are these? Counter-mapping forest territories in Kalimantan, Indonesia. Antipode, 27. pp. 383-406.

Rocheleau, D., \& Ross, L. (1995). Trees as tools, trees as text: Struggles over resources in ZambranaChacuey, Dominican Republic. Antipode, 27. pp. 407-428.

Scoones, I. (1998). Sustainable rural livelihoods: A framework for analysis. Working Paper, 72. IDS: Brighton, UK.

Scoones, I., \& Thompson, J. (1994). Beyond farmer first: Rural people's knowledge, agricultural research and extension practice. (eds). Intermediate Technology Publications: London, UK.

Sopanah, A., \& Wahyudi, I. (2005). Strategi Penguatan Masyarakat Sipil dalam Meminimalisasi Distorsi Penyusunan APBD Kota Malang (The Strategy of Community Strengthening in order to Minimized Budget Distortion in Malang Municipality). In Simposium Riset II ISEI "Percepatan Pertumbuhan Ekonomi dan Pengurangan Pengangguran. 23-24 November. Surabaya.

Syarifuddin. (2011). Konstruksi Kebijakan Anggaran: Aksentuasi Drama Politik dan Kekuasaan (Budget Policy Construction: Drama Accentuation of Politic and Power). Jurnal Ekuitas, Vol. 15 No. 3. pp. 307-331.

Peraturan Pemerintah Nomor 8 tahun 2008 tentang Tahapan, Tata Cara Penyusunan, Pengendalian, dan Evaluasi Pelaksanaan Rencana Pembangunan Daerah (Government Regulation Number 8 of 2008 concerning Stages, Procedures for Preparation, Control and Evaluation of the Implementation of Regional Development Plans). 
Undang-undang No. 23 tahun 2014 tentang Perencanaan Pembangunan (Law No. 23 of 2014 concerning Development Planning).

Undang-undang No. 25 tahun 2004 tentang Sistem Perencanaan Pembangunan Nasional (Law No. 25 of 2004 concerning the National Development Planning System). 